JPE (Jurnal Pendidikan Edutama) Vol. 5 No. 2 Juli 2018

P-ISSN : 2339-2258 (Print) E-ISSN: 2548-821X (Online)

http://ejurnal.ikippgribojonegoro.ac.id/index.php/JPE

\title{
PENINGKATAN KOMPETENSI PROFESIONAL GURU KEWIRAUSAHAAN MELALUI LESSON STUDY BERBASIS PANTAI DAN LAUT
}

\author{
Siti Sri Wulandari \\ Fakultas Ekonomi, Universitas Negeri Surabaya \\ sitiwulandari@unesa.ac.id
}

\begin{abstract}
The objective of the research is to improve the professionalism of entrepreneurship teachers in making the implementation plan of learning in accordance with the potential of coastal and marine natural resources in Sidoarjo Indonesia, is expected to be able to create innovative products from coastal and marine resources resources in the coastal and marine based learning plan. The sample was taken by using purposive sampling technique, that is entrepreneurship teacher who attended the lesson study activity based on beach and sea that amounted to 35 of 90 entrepreneurship teachers in Sidoarjo. Data collection using interview technique, documentation, and observation. The data obtained will be analyzed using qualitative with quantitative approach where data are analyzed using percentage formula, analyzed through three activity paths that focus activity, simplify and transfer from rough data to field notes, display data and deliver final result. The conclusion of coastal and marine based study lesson study is very potential in improving the professionalism of entrepreneurship teachers in improving the quality of learning and learning outcomes of learners and can increase student entrepreneurship interest when they finish studying in formal education.
\end{abstract}

Keywords: Teacher Professional Competency, Lesson Study, Coastal Ecosystem

\begin{abstract}
Abstrak: Pembuatan perencanaan pelaksnaan pembelajaran berbasis pantai dan laut bagi guru kewirausahaan di Sidoarjo Indonesia dalam meningkatkan profesionalitasnya sebagai guru merupakan tujuan dari penelitian ini. Harapannya guru kewirausahaan mampu menciptakan produk inovatif dari sumber daya pantai dan laut yang direncanakan dalam pelaksanaan pembelajaran kewirausahaan berbasis pantai dan laut. Jumlah sampel yang diambil sebanyak 35 orang dari 90 orang anggota musyawarah guru mata pelajaran kewirausahaan di Sidoarjo dengan menggunakan teknik purposive sampling. Pengumpulan data mengunakan teknik wawancara, dokumentasi, dan pengamatan. Analisis data menggunakan deskriptif kualitatif dengan pendekatan kuantitatif dimana data dianalisis menggunakan formula presentase, dianalisis melalui tiga alur kegiatan yakni kegiatan memfokuskan, menyederhanakan dan mentransfer dari data kasar ke catatan lapangan, menampilkan data dan menyampaikan hasil akhir. Kesimpulannya bahwa lesson study pada guru kewirausahaan di Sidoarjo yang berbasis pantai dan laut mampu meningkatkan profesionalisme guru kewirausahaan sehingga meningkatkan kualitas pembelajaran, keaktifan siswa dan hasil belajar siswa serta meningkatkan minat berwirausaha siswa.
\end{abstract}

Kata Kunci : Kompetensi Profesional Guru, Lesson Study, Lingkungan Pesisir Pantai Laut 


\section{PENDAHULUAN}

Kegiatan yang dilakukan seseorang dengan lingkungan sekitarnya untuk mendapatkan pengetahuan yang kompleks dalam kehidupannya adalah sebuah proses belajar. Interaksi seseorang dengan lingkungannya merupakan sebuah proses pembelajaran (Musfiqon, 2012:6). Pendapat Sharon E. Smaldino dan James D. Russel "Instructional Technology and Media for Learning", belajar merupakan suatu proses mengembangkan pengetahuan baru, perilaku dan ketrampilan dari interaksi individu dengan lingkungannya (Musfiqon, 2012:6). Sedangkan untuk mencapai tujuan pembelajaran guru harus mampu menjadi agen pembelajaran dimana guru memiliki peran dalam menginspirasi belajar siswa, mampu memotivasi belajar, mampu menjadi media dalam memfasilitasi komunikasi sehingga siswa menjadi aktif dan mampu melihat kebutuhan dan potensi yang dimiliki siswa.

Keempat kompetensi tersebut selaras dengan kebijakan peningkatan mutu pendidikan dewasa ini yang semakin diarahkan pada perluasan inovasi pembelajaran, dalam rangka mewujudkan proses yang effisien, menyenangkan dan mencerdaskan, sesuai tingkat usia, kematangan, serta tingkat perkembangan peserta didik.

Mengacu kepada UndangUndang Nomor 14 tahun 2005 yang menyatakan, kedudukan pendidik sebagai tenaga pengajar berfungsi untuk peningkatan mutu pendidikan nasional melalui peningkatan kompetensi dan peran guru sebagai agen of change dalam proses belajar mengajar. Namun demikian, mengacu pada hasil uji kompetensi guru yang dilakukan oleh Kementerian Pendidikan dan Kebudayaan bahwa hasil uji kompetensi guru yang merupakan nilai kemampuan pedagogik guru belum optimal. Hal ini terlihat dari beberapa indikator, antara lain: kualitas pelatih yang masih bervariasi sehingga upaya pengimbasan kemampuan dan pengalaman kepada guru lainnya belum optimal, fokus perhatian masih berorientasi pada substansi pelajaran dan kurang memperhatikan kebutuhan dan yang sedang dipelajari siswa, serta sebagian besar proses pembelajaran di kelas masih menggunakan komunikasi satu arah.

Data Kementerian Pendidikan dan Kebudayaan menunjukkan bahwa nilai uji kompetensi guru masih rendah rata-rata uji kompetensi guru nasional yaitu kemampuan pedagogik dan professional sebesar 53,02, sedangkan kriterian ketuntasan minimal yang ditargetkan pemerintah adalah 55.00. Jika dipilah, rerata nilai uji kompetensi guru untuk kompetensi profesional 54,77 , sedangkan nilai rata-rata kompetensi pedagogik 48,94.

Berdasarkan pada UndangUndang Nomor 14 tahun 2005 pasal 1 ayat (4) yaitu: seseorang yang memiliki pekerjaan yang membutuhkan pendidikan profesi sehingga memiliki keahlian dan ketrampilan sesuai dengan standar mutu merupakan sebuah profesionalitas, dan dapat dijadikan sumber penghasilan untuk membiayai kehidupan sehari-hari. Pernyataan yang lebih rinci disampaikan oleh Suyanto (2001) bahwa untuk mencapai tataran ideal guru professional seorang guru membutuhkan sebuah pelatihan yang dilaksanakan secara berkelanjutan. Pendapat yang sama disampaikan oleh Alba, G.D \& Sandberg (2006: 384) yaitu konsep pengembangan profesional tidak dibatasi dengan jelas. Profesi secara tradisional didefinisikan sebagai pengetahuan sains yang sistematis. 
Pengembangan awal dalam keterampilan profesional telah menjadi program pendidikan tinggi yang ditunjuk, dengan perkembangan selanjutnya mengambil berbagai bentuk.

Dalam arti bahwa untuk mengembangkan kompetensi profesionalitas guru tidak ada pembatas. Pengetahuan ilmiah dan sistematis dapat dikatakan sebagai suatu profesi. Dapat diartikan bahwa profesi guru dalam melakukan tugas profesinya mengajar siswa akan menjadi lebih efektif dan efisien. Hal yang sama diutarakan oleh Bybee dan Loucks-Horsley (2001:4) Guru memiliki peluang untuk mengetahui kebutuhan siswa dan bagaimana cara melaksanakannya sesuai kompetensi yang diharapkan dan tujuan pembelajaran yang akan dicapai merupakan bagian dari pengembangan keprofesionalan. Pernyataan diatas memperlihatkan bahwa kemampuan mengembangkan diri dengan cara adaptasi dengan perkembangan zaman dan lingkungan sekitarnya haruslah dimiliki oleh guru sekolah menengah kejuruan dalam melaksanakan pengajaran di sekolah.

Pelajaran menggunakan Lesson Study menurut (Dirjen PMPTK : 2008) terdapat tiga sesi utama yakni: (1) Sesi merencanakan (planning): untuk mendesign perangkat pembelajaran, menstimulus peserta didik untuk aktif dan interaktif ketika proses belajar mengajar berlangsung di kelas;(2) Sesi implementasi (implementing): yang bertujuan melaksanakan design pembelajaran yang sudah dirumuskan dan direncanakan oleh guru. Perencanaan yang dibuat sekaligus dipakai untuk menunjuk guru model yang akan menerapkannya di dalam kelas. Tujuannya untuk mengetahui efektifitas model pembelajran yang sudah dibuat.
(3) Sesi refleksi (reflecting/see): proses berdiskusi dan berkolaborasi sesama pengamat proses pembelajaran yang sudah diterapkan guru model untu menilai implementasi dari kegiatan lesson study yang telah dilakukan.

Namun demikian, sampai saat ini Sidoarjo dalam capaian pembelajaran tertinggi baru sampai pada penerapan pembelajaran berbasis adiwiyata dimana sekolah menata pembelajaran dan lingkungan belajarnya sedemikian rupa agar siswa dapat berperilaku tanggung jawab terhadap lingkungan. Lingkungan yang diminiaturkan dalam adiwiyata adalah lingkungan di darat. Hal ini tentu belum mencakup lingkungan yang berbatasan dengan pantai dan laut sebagaimana beberapa daerah di Sidoarjo yang langsung berbatasan dengan laut, yaitu Selat Madura.

Berbagai kegiatan pemberdayaan yang dilakukan di wilayah pesisir pantai dan laut terhadap subsektor perikanan laut yang merupakan sumber mata pencaharian dan kesejahteraan bagi 13,6 juta orang, dan secara tidak langsung mendukung kegiatan ekonomi bagi sebagian besar penduduk Indonesia yang bermukim di wilayah pesisir (Dahuri .1996). Menurut Pulukadang dan Sya'roni dalam Yuliastutik (2003), sebagai "tapal batas terakhir", laut menawarkan berbagai peluang usaha untuk dikembangkan, terutama untuk masa-masa mendatang.

Hal tersebut senada dengan pendapat Nybaken (1992) Daerah yang memiliki kedalaman kurang dari 200 meter disebut pantai. Menurut Wibisono (2005) Pantai merupakan perbatasan antara wilayah darat dan wilayah laut. Sedangkan Lingkungan pantai adalah lingkungan yang berada di perbatasan dengan lingkungan pasang surut,darat dan laut. Potensi sumber daya laut dapat 
membantu masyarakat pesisir dalam memenuhi kebutuhan hidupnya. Beraneka ragam ekosistem yang ada di daerah pesisir akan memiliki banyak manfaat satu dengan lainnya dan membuat sitem ekologi unik. (Tuwo.2011).

Untuk itu, masyarakat Sidoarjo harus kreatif dan inovatif dalam memenuhi kebutuhan dengan cara yang tepat dan benar agar kepentingan kepentingan peningkatan kesejahteraan tidak mengorbankan kelestarian sumber daya alam dan lingkungan pesisirnya.

Berdasarkan penjelasan di atas maka yang menjadi permasalahan utama adalah bagaimana meningkatkan professional guru kewirausahaan melalui lesson study berbasis pantai dan laut? Peningkatan professional guru kewirausahaan mampu memberikan maanfaat bagi ilmu pengetahuan, sekolah, guru kewirausahaan, siswa, dan peneliti.

\section{METODE PENELITIAN}

Metode yang digunakan adalah deskriptif kualitatif dengan study kasus di Sidoarjo, dengan subyek penelitian adalah guru-guru kewirausahaan berjumlah 35 orang yang tergabung dalam musyawarah guru mata pelajaran kewirausahaan. Informasi data diperoleh melalui observasi, wawancara dan dokumentasi/produk rencana pelaksanaan pembelajaran berbasis pantai dan laut. Analisis data menggunakan deskriptif kualitatif. Menurut Saldana (2011:95). Qualitative data analysis is concurrent with data collection and management." Sedangkan menurut Miles dan Hubberman (1992:20) menyatakan bahwa kegiatan yang dilakukan berulang-ulang, dan terus menerus serta berkelanjutan merupakan bentuk menganalisis data kualitatif".
Berdasarkan proses analisis data menggunakan teori Miles, dan Huberman di atas, analisa data kualitatif terdiri dari 3 tahap yaitu: mengumpulkan data (reduksi data), menyajikan data, menarik kesimpulan. Kegiatan yang akan dilakukan dalam penelitian ini sebagai berikut:

\section{1) Perencanaan}

Mengidentifikasi masalah yang terjadi pada guru kewirausahaan yang tergabung dalam MGMP guru kewirausahaan di Sidoarjo. Hasil identifikasi digunakan dalam mendesign model pembelajaran sesuai kebutuhan dan mendiskusikan melalui untuk mengatasi permasalahan pembelajaran, kemudian menyusun dan mengemasnya menjadi sebuah scenario kegiatan belajar mengajar berupa perencanaan pelaksanaan pembelajaran berbasis pantai dan laut. Adapun aspekaspek yang diamati dalam proses merencanakan pembelajaran berbasis pantai dan laut yang meliputi kemampuan identitas rencana pelaksanaan pembelajaran yang terdiri dari komponen rencana pelaksanaan pembelajaran yaitu pedagogic, prinsip konstektual, berbasis pantai dan laut.

\section{2) Pelaksanaan}

Kegiatan yang dilakukan adalah mengamati kemampuan guru model dalam mengimplementasikan pembelajaran berbasis pantai dan laut. Pengamatan dilakukan para ahli dan peserta lesson study yakni para guru dengan menggunakan instrument lembar pengamatan. Aspek yang diamati dalam implementasi pembelajaran berbasis pantai dan laut meliputi: a) kemampuan membuka berupa kegiatan apersepsi dan motivasi, menjelaskan tujuan dan rencana kegiatan, b) kemampuan inti yang terdiri dari menjelaskan materi 


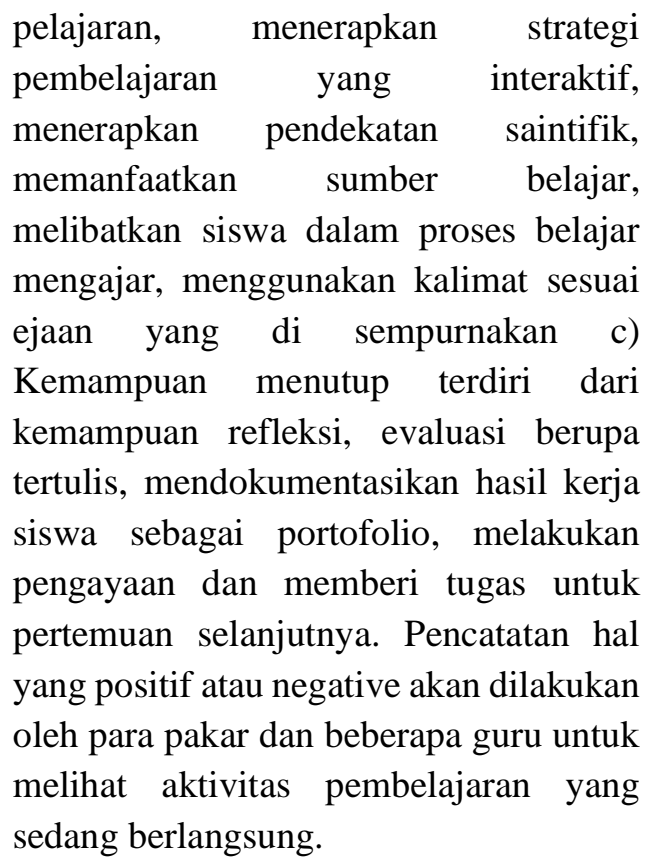

\section{3) Tahap Refleksi}

Hasil pengamatan baik yang bersifat positif maupun negative akan didiskusikan oleh para ahli dan pengamat lainya serta guru model sendiri. Kegiatan diskusi yang pertama dilakukan adalah bagaimana penerapan model pembelajaran yang sudah dirancang oleh guru. Selanjutnya pengamat menganalisis hasil data yang berkaitan dengan pelaksanaan kegiatan proses belajar mengajar di kelas, sesi berikutnya pengamat dan para ahli menilai dengan cara memberikan komentar berupa saran dan masukan pada kegiatan yang sudah dilaksanakan.

Data hasil observer kemudian dianalisis dengan skala likert. Menurut beberapa ahli, yaitu Likert (1932), Hall (1934), metode summatted ratings (metode yang digunakan dalam skala likert) lebih sederhana dan lebih mudah dalam mengaplikasikan pada pengembangan skala sikap daripada metode equal appearing interval.

\section{HASIL DAN PEMBAHASAN}

a) Berdasarkan hasil observasi kemampuan guru kewirausahaan dalam merencanakan pelaksanaan pembelajaran kewirausahaan berbasis pantai dan laut. Dapat diketahui bahwa kemampuan pedagogic guru menunjukkan nilai $75 \%$ masuk dalam kategori Baik. Kemampuan pedagogic guru terdiri dari kompetensi pendekatan strategi, metode, dan teknik pembelajaran. Kompetensi menyusun silabus, rencana pelaksanaan pembelajaran sesuai tujuan kurikulum dan lingkungan pembelajaran basis pantai dan laut. Dan kesesuaian materi dengan tujuan pembelajaran. Pembelajaran konstekstual nilai $80 \%$ masuk dalam kategori Sangat Baik. Rencana pelaksanaan pembelajaran kewirausahaan yang bertema pantai dan laut nilanya $84 \%$ masuk kategori Sangat Baik. Sehingga rata-rata dari hasil pembuatan rencana pelaksanaan pembelajaran kewirausahaan berbasis pantai dan laut adalah $79 \%$ dan masuk dalam kategori sangat baik.

b) Berdasarkan pengamatan peneliti menunjukkan bahwa proses pembelajaran berbasis pantai dan laut telah konsisten dilaksanakan oleh guru model. Hasil penilaian micro teaching Kemampuan guru model dalam melaksanakan pembelajaran kewirausahaan berbasis pantai dan laut melalui lesson study yang terdiri dari Kegiatan Membuka, Kegiatan Inti Pembelajaran, Kegiatan Menutup.

Hasil kegiatan dapat diketahui bahwa kemampuan guru model dalam melaksanakan rencana pelaksanaan pembelajaran mata pelajaran Kewirausahaan Berbasis Pantai dan laut mendapat nilai 84 termasuk kategori sangat baik. Pada kegiatan pendahuluan menunjukkan bahwa aspek appersepsi dan motivasi mendapat angka 85 dan 88 masuk kategori sangat baik. Pada kegiatan Inti ada 6 aspek yang masuk 
kategori sangat baik dengan nilai diatas 75 yaitu penerapan strategi pembelajaran yang mendidik, penerapan pendekatan kontekstual, memanfaatkan lingkungan sebagai sumber belajar, melibatkan siswa secara aktif dan interaktif dan menggunakan kalimat yang tepat dalam pembelajaran, hanya pada aspek penguasaan materi yang mendapat kategori baik dengan nilai 75 . Pada kegiatan penutup masuk kategori sangat baik dengan nilai 81 , sebab guru model sudah melakukan refleksi dengan melibatkan siswa secara interaktif, dan memberikan evaluasi berupa tes tulis serta mendokumentasikan hasil kerja siswa sebagai bahan portofolio.

c) Pada tahap refleksi guru model memberi ulasan tentang pembelajaran yang sudah dilakukan yakni pembelajaran kewirausahaan berbasis pantai dan laut. Salah satu usaha yang dilakukan dengan mengembangkan tema yang dekat dengan kehidupan siswa yaitu pantai dan laut.

Melalui lesson study para guru kewirausahaan dapat meningkatkan kompetensi profesionalitasnya semua bekerja bersama-sama dengan antusiame yang tinggi mengeluarkan ide inovatif dan kreatif dalam mengembangkan rencana pelaksanaan pembelajaran berbasis pantai dan laut. Implikasi rencana pelaksanaan pembelajaran berbasis pantai dan laut akan bermanfaat bagi siswa karena belajar bagaimana memanfaatkan potensi alam pesisir pantai laut di daerah Sidoarjo. Dengan memakai media dan metode pembelajaran menggunakan pendekatan kontekstual yang mengkaitkan materi dengan dunia nyata dan penilaian autentik siswa baik kognitif, psikomotor, afektif. Hasil belajar kewirausahaan yang diterapkan guru akan menarik minat siswa menjadi seorang wirausaha muda.
Kegiatan lesson study yang dilakukan guru kewirausahaan berbasis pantai dan laut sangat baik bisa dilihat dari hasil nilai rata-rata siswa mulai apersepsi dan penggalian konsepsi awal. Senada dengan teori yang dikemukakan oleh Sukirman (2006:2) kegiatan merencanakan, melaksanakan, dan merefleksikan adalah tahapan lesson study

Kegiatan yang dilakukan pada tahapan (plan) yaitu para peserta lesson study diminta merencanakan atau mengkonsep materi-materi, mendesign kegiatan belajar mengajar dan membuat lembar pengamatan dan penilaian untuk siswa. Mereka juga diminta untuk berdiskusi dalam menentukan media, mode dan metode pembelajaran yang tepat melalui pendekatan saintifik. Para peserta lesson study terlihat begitu akrab dan terbuka dalam sesi perencanaan.

$$
\text { Tahap berikutnya yaitu }
$$
pelaksanaan (do) dimana guru yang dipilih menjadi guru model yang akan berusaha menerapkan pendekatan saintifik atau student center dengan mengajak siswa aktif dalam proses belajar mengajar di kelas. Contoh kegiatan guru model adalah membuka dan menjelaskan tujuan dan materi pelajaran, menstimulus siswa dengan cara variasi bertanya dalam kelas supaya siswa aktif menjawab pertanyaan yang diberikan guru model, dan tidak memperbolehkan siswa menjawab pertanyaan dari temannya. Terlihat kondisi di kelas sangat aktif dan sangat antusias ketika melaksanakan percobaan. Dalam mengikuti kegiatan belajar mengajar di kelas, terlihat kegiatan interaksi siswa dan guru sangat baik, keaktifan siwa dengan guru maupun dengan sesama teman juga masuk kategori sangat baik, begitu juga dengan bahan ajar, siswapun mampu 
melaksanakan uji coba di kelas. inovasi pebelajaran yang dilaksanakan masih belum bisa meningkatkan berfikiri kritis kritis serta ide-ide kreatif siswa. Maka solusi dari permasalahn di atas yaitu guru harus meningkatkan kemampuan mengelola kelas, menciptakan suasana belajar yang menyenangkan, membuat variasi pembelajaran sehingga dapat meningkatkan berfikir kritis dan aktifitas dan hasil belajar siswa.

Pendapat yang sama dikemukakan oleh Richard D. Kellough (1998) dalam Danim (2011) Guru yang professional adalah yang memiliki ketrampilan mengajar diantaranya menguasai materi pelajaran dan memiliki pengetahuan luas dengan materi yang akan diajarkannya, sebagai bagian dari anggota organisasi profesi guru yang aktif, senang mencari dan membaca referensi yang berasal dari jurnal professional, mengikuti forum musyawarah guru mata pelajaran (MGMP) untuk memudahkan komunikasi antar sesama guru, meningkatkan ketrampilan dan membuat assessment pembelajaran, meningkatkan kreatifitas guru dalam variasi strategi pembelajaran kewirausahaan serta professional dalam setiap kesempatan. Siswa sudah dibekali guru kewirausahaan bagaimana memanfaatkan dan mengolah sumber daya pantai dan laut di daerah masingmasing. Senada dengan yang disampaikan oleh Purwanto (2010:45) bahwa hasil belajar merupakan perubahan yang mengakibatkan manusia berubah dalam sikap dan tingkah lakunya. Pendidikan diharapkan dapat mengedukasi masyarakat pesisir untuk lebih kreatif dalam mengolah dan memanfaatkan hasil laut sehingga dapat meningkatkan pendapatan penduduk.
Pembelajaran konteksual atau contextual learning merupakan pembelajaran dengan cara memanfaatkan pantai dan laut untuk obyek/tema pembelajaran. Sesuai dengan pendapat Wina (2006:253) bahwa pendekatan kontekstual merupakan strategi pembelajaran yang menekankan pada proses keterlibatan siswa secara penuh untuk dapat menemukan materi yang dipelajarinya dan menghubungkannya dengan kondisi lingkungan sekitarnya atau kehidupan nyata. Melalui kegiatan lesson study akan sangat membantu guru dan siswa dalam mengaitkan materi dengan kenyataan. Disinilah peran guru kewirausahaan khususnya di kabupaten Sidoarjo dalam merancang model Rencana Pelaksanaan Pembelajaran berbasis pantai dan laut sehingga potensi local pantai melalui pendekatan kontekstual. Hasil dari pembelajaran kontekstual membuat siswa mendapatkan pengalaman yang bermakna setelah menamatkan jenjang sekolah menengah atas dan mampu memperbaiki perekonomian keluarga melalui jalur pendidikan.

Berdasarkan pengamatan selama kegiatan lesson study tersebut kemampuan pedagogic dan professional guru semakin meningkat. Rencana pembelajaran yang dibuat guru di sekolah masing-masing cukup bervariasi. Langkah-langkah belajar masih banyak kekurangan salah satunya yaitu pada kegiatan awal yaitu apersepsi, kemudian pada saat kegiatan inti guru dalam menggunakan strategi pembelajaran kurang kreatif yang menyebabkan motivasi dan keaftifan siswa di dalam kelas. Selain itu media pembelajaran dan alat evaluasinya perlu dikembangkan lagi dengan cara memanfaatkan teknologi informasi computer (TIK). Adapun sisi positif dari kegiatan lesson study ini 
adalah dapat mengatasi perencanaan Tahap pelaksanaan rencana dinilai baik. Kegiatan pembelajaran yang dilakukan guru model dalam menciptakan kegiatan belajar mengajar melalui lesson study dinilai sangat menarik dan membuat siswa aktif dan tidak mdah bosan. Konsep lebih mudah dijelaskan oleh guru dan siswa lebih cepat menemukan konsep melalui eksplorasi. Terdapat langkah-langkah dalam setiap model pembelajaran yang digunakan, keterkaitan antara tahapan perencanaan dan pembelajaran yang menyebabkan proses belajar mengajar menjadi lebih baik di lihat dari struktur pembelajaran yang baik. Beberapa indicator dari hasil pengamtan dapat dikatakan terampil dengan kategori baik yaitu kemampuan guru dalam menguasai materi, pemakaian media pembelajaran, ketrampilan mengelola kelas, keterampilan tanya jawab dan keterampilan dalam memotivasi siswa.

Di dukung oleh pernyataan Bybee dan Loucks Horsley (2001:4) bahwa guru memiliki kesempatan mengetahui kebutuhan siswa dan bagaimana cara melaksanakannya sesuai kompetensi yang diharapkan dan tujuan pembelajaran yang akan dicapai merupakan bagian dari pengembangan keprofesionalan. Pernyataan di atas mendukung bagaimana seharusnya seorang guru sekolah menengah kejuruan harus mampu mengembangkan profesi pendidik dan menjalankan tugasnya dengan cara menyesuaikan materi dan kebutuhan siswanya sesuai dengan perkembangan zaman dan lingkungan sekitar sekolah sebagai sebuah kompetensi professional dan pedagogic yang harus dimiliki. Keterlibatan sekolah sangat berpengaruh dalam upaya meningkatkan kompetensi professional dan pedagogic guru. Selain pihak sekolah, ada pula peran pemerintah pusat dan pemerintah daerah yang ikut membina dalam mengembangkan kualifikasi dan kompetensi guru serta berkewajiban membantu program peningkatan professional guru sesuai dengan undang-undang no.14 tahun 2005.

\section{SIMPULAN}

Peningkatan profesionalisme guru kewirausahaan dapat dilakukan melalui kegiatan lesson study berbasis pantai dan laut. Hasil temuan menunjukkan kemampuan guru kewirausahaan dalam merencanakan dan mengimplementasikan pembelajaran kewirausahaan meningkat lebih baik melalui kegiatan lesson study berbasis pantai dan laut. Pembelajaran berbasis pantai dan laut mampu meningkatkan kemampuan dan kreativitas dan inovasi guru kewirausahaan dalam pembuatan model pembelajaran berbasis pantai dan laut dalam bentuk rencana pelaksanaan pembelajaran yang baik. Rata-rata kualitas rencana pelaksanaan pembelajaran yang dikembangkan guru kewirausahaan sudah baik. Sebaiknya para guru kewirausahaan senantiasa meningkatkan kemampuan pedagogik, meningkatkan ide-ide inovatif dan kemampuan kreativitasnya dalam menggunakan model-model pembelajaran dan metode pembelajaran yang interaktif dengan pendekatan konstektual sehingga pembelajaran menjadi bermakna bagi siswa.

\section{DAFTAR RUJUKAN}

Dahuri, 1996. Pengelolaan Sumberdaya Wilayah Pesisir dan Lautan Secara Terpadu. Jakarta: Pradya Paramita.

Dirjen PMPTK, (2008). Pedoman Pelaksanaan MGMP Berpola Lesson Study. Jakarta : JICA. 
Hall, S. 2010. "How to Use the Likert Scale in Statistical Analysis."

Lewis, C. (2002). Lesson Study: A Handbook of Teacher-Led Instructional Change. Philadelphia, PA: Research for Better Schools, Inc.

Huberman, A.M. dan Miles, M.B. 1992.Analisis Data Kualitatif. Jakarta : UIPress. Jakarta.

Leksono, A.S. (2007). Ekologi: Pendekatan Deskriptif dan Kuantitatif. Malang: Bayumedia Publishing.

Killeavy, Maureen and Anne Moloney (2010) "Reflection in a social space: can blogging support reflective practice for beginning teachers?". Teaching and Teacher Education 26, 1070-1076.

Markusic, Mayflor. 2009. "Simplifying the Likert Scale."

Sparks, D. 1999. Overview of Lesson Study. [Online]. Tersedia: http://www.nwrel.org/msec/lessons tudy/overview.html. [27 Juni 2006].

Shoffner, Melanie (2009) "The place of personal: exploring the affective domain through reflection in teacher preparation". Teaching and Teacher Education 25, 783-789.

Sukirman. 2006. Peningkatan Profesionalisme Guru Melalui Lesson Study. Makalah Disampaikan Pada Kegiatan Pelatihan 2 Hari untuk Fasilitator dan Tim TPK SISTTEMS Bantul Emergency Program Pada 11 - 12 Agustus 2006.

Trochim, William M.K. 2006. "Likert Scaling." Research Methods Knowledge Based.

Undang-Undang Republik Indonesia Nomor 14 Tahun 2005 Tentang Guru dan Dosen.
Wina Sanjaya. 2006. Strategi Pembelajaran Berorientasi Standar Proses Pendidikan. Jakarta:Kencana.

Yuliastutik, E. 2003. Pengaruh Status Sosial Terhadap Pola Konsumsi Pangan Keluarga Nelayan. Skripsi. Jember: Universitas Jember. 
78 JURNAL PENDIDIKAN EDUTAMA, Vol 5, No. 2, Juli 2018 